\title{
SPECTRAL PROPERTIES AND POLYPEPTIDE COMPOSITION OF THE CHLOROPHYLL-PROTEINS FROM THYLAKOIDS OF GRANAL AND AGRANAL CHLOROPLASTS OF MAIZE (Zea mays L.).
}

\author{
by \\ ROBERTO BASSI ${ }^{1)}$ \\ Department of Physiology, Carlsberg Laboratory, \\ Gamle Carlsberg Vej 10, DK-2500 Copenhagen Valby \\ ${ }^{1}$ Permanent address: Dipartmento di Biologia, via Orto Botanico 35, 35100 Padova, Italy
}

Keywords: Bundle sheath and mesophyll thylakoids, absorption spectra, fluorescence emission spectra, circular dichroism spectra, light harvesting complex I and II

In contrast to the granal thylakoids of mesophyll cells, the bundle sheath thylakoids of maize lack photosystem 11 activity and both of the chlorophyll $a$ binding proteins of photosystem II. The chlorophyll-proteins from bundle sheath and mesophyll thylakoids are separated by undenaturing electrophoresis and after isolation characterized by SDS-urea-PAGE and spectroscopy. The chlorophyll-protein with the highest molecular mass $\left(\mathrm{Chl}_{a}-\mathrm{P} 1^{*}\right)$ is shown to consist of the reaction centre I containing chlorophyll-protein $\left(\mathrm{Chl}_{a}-\mathrm{Pl}\right)$ and 12 other polypeptides. Three of the polypeptides are components of the chlorophyll $a / b$-protein $\mathrm{P} 3$, which by its fluorescence emission and absorption spectrum is recognized as PSI antenna.

The oligomeric chlorophyll $a / b$-protein $2^{* *}$ consists of the $\mathrm{Ch}_{a / b}-\mathrm{P} 2$ polypeptides plus a polypeptide $\mathrm{R}$ with an apparent molecular weight of 7.800 .

The bundle sheath thylakoids contain large amounts of the light harvesting complex of the photosystem II which transfers energy efficiently to the PSI reaction centre in absence of the PSII reaction centre.

\section{INTRODUCTION}

All photosynthetic pigments are organized within the thylakoids as discrete lipoprotein units: the chlorophyll-protein complexes (CPs). These bind either only chloropyll (chl) $a$ or both chl $a$ and $b$. By using nondenaturing SDSPAGE, the following CPs have been described that bind only $\operatorname{chl} a: \mathrm{Chl}_{a}-\mathrm{Pl}$ (CP1) belonging to the photosystem I (PSI) reaction centre and
$\mathrm{Chl}_{\mathrm{a}}-\mathrm{P} 2$ and $\mathrm{Chl}_{a}-\mathrm{P} 3$ (cpas) belonging to the photosystem II (PSII) reaction centre (2, 3, 14 , 37).

The light harvesting chlorophyll protein complex of the PSII (LHCII), which contains about equal amounts of $\operatorname{chl} a$ and $b$, appeared to be the only fully characterized $\mathrm{chl} b$ binding $\mathrm{CP}$ in thylakoids of higher plants $(19,53)$. Recently the presence of a chl $a / b$ containing CP (LHCI)

Abbreviations: $\mathrm{AP}=$ apoprotein $\mathrm{chl}=$ chlorophyll $\mathbf{C P}=$ chlorophyll-protein $\mathbf{C P 1}=$ chlorophyll-protein complex 1; DCMU = dichlorophenyl dimethyl urea; DCPIP = dichlorophenolindophenol; EDTA = ethylene diamino tetracetic acid; $\mathrm{LHCl}=$ light harvesting complex of the photosystem $\mathrm{I}$; LHCII = light harvesting complex of the photosystem II; PAGE = polyacrylamide gel electrophoresis; PSI-1 10,60,45 = Photosystem I preparations binding respectively $110,60,45 \mathrm{chl}$ molecules per reaction centre; $\mathrm{RCI}=$ reaction centre $\mathrm{I}$; Tricine $=\mathrm{N}$-(tris(hydroxymethyl)methyl)glycine; SDS = Sodium dodecylsulphate; Tris = Tris-(hydroxymethyl)amino methane 
associated with PSI has been described in several higher plants and green algae $(25,28,29,30,49$, 56 ). $\mathrm{LHCI}$ has a higher chl $a / b$ ratio than LHCII and has been inferred to contain 1-5 polypeptides with molecular weights of $20-25 \mathrm{kD}$ ( 30 , 40). This CP is enriched in stroma membranes (33) which contain mainly PSI (4) and its function as an antenna for PSI has been recently discussed (47).

Although LHCII is associated mainly with PSII in the grana region of the photosynthetic membrane $(4,41,51)$ it is considered to transfer energy to PSI under some conditions. It has been proposed that phosphorylation of this complex by a thylakoid bound kinase regulates the transfer of the energy absorbed by LHCII to PSI and PSII in response to the redox condition of the plastoquinone pool $(1,54)$. The photosynthetic membrane of agranal bundle sheath plastids of Zea mays completely lacks the two chl $a$ binding proteins of PSII (13). The chl $a / b$ ratio is higher (between 5 and 6) than in mesophyll plastid membranes. Nevertheless, detectable amounts of LHCII are present.

The simple organization of the bundle sheath plastids where only the PSI reaction centre is present, makes them a useful tool to study the relations between the PSI reaction centre and the two LHCs.

I have studied the spectral properties of the thylakoids from bundle sheath and mesophyll of maize. Their CPs are characterized with respect to absorbance spectra, $77 \mathrm{~K}$ fluorescence emission and polypeptide composition. It is possible to distinguish between LHCI and LHCII in both bundle sheath and mesophyll thylakoids. In gel slices, the $732 \mathrm{~nm}$ fluorescence emission at $77 \mathrm{~K}$ typical of $\mathrm{LHCI}$ is small relative to the intense emission at $680 \mathrm{~nm}$ from $\mathrm{Chl}_{a}-\mathrm{P} 2$ in gels from mesophyll membranes.

It is concluded that in bundle sheath thylakoids both LHCI and LHCII are able to transfer energy to the PSI reaction centre.

Diverse nomenclatures of CPs are in use in

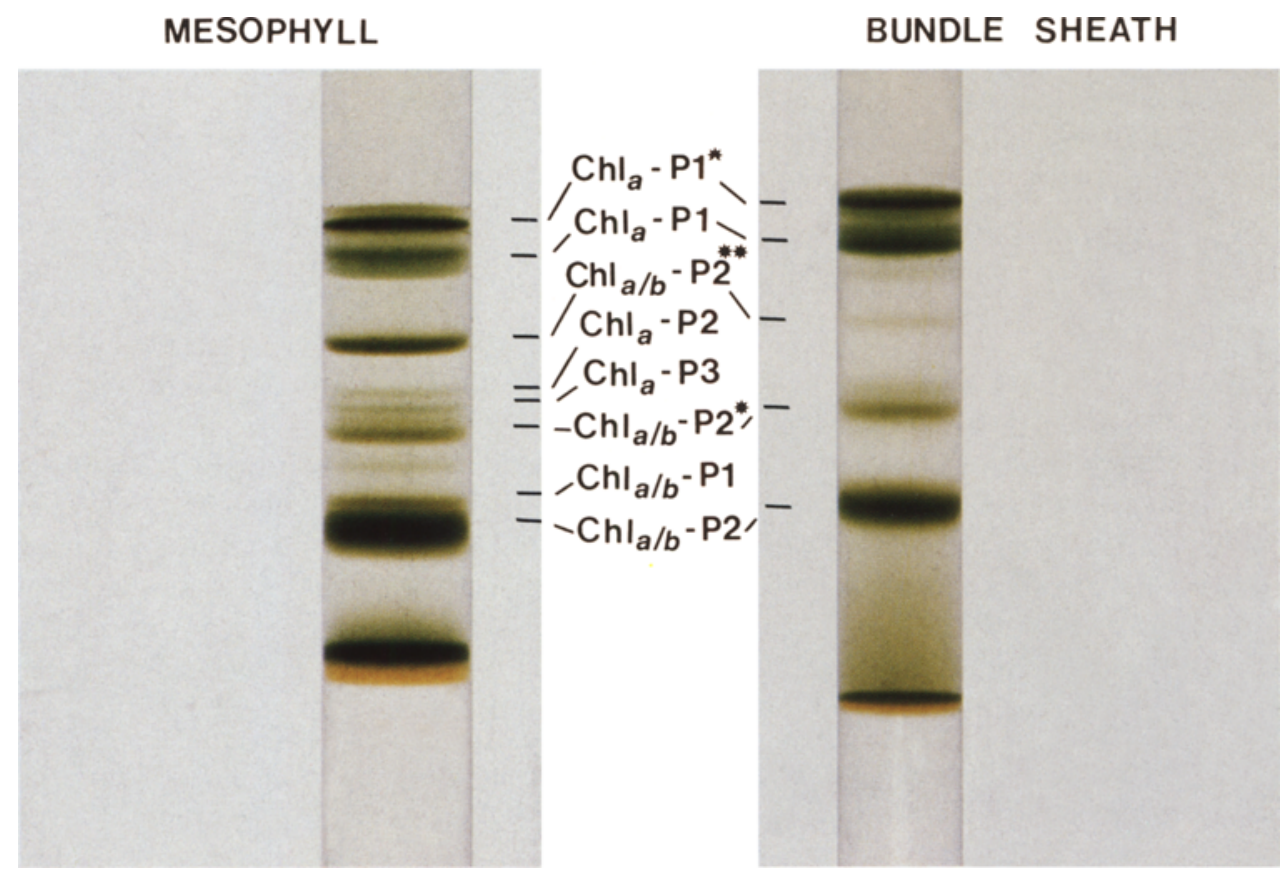

Figure 1. Nondenaturing SDS-PAGE of chlorophyll proteins from bundle sheath and mesophyll membranes. $25 \mu \mathrm{g}$ of $\mathrm{chl}$ were applied to each tube. 
different laboratories and organisms. In this paper the nomenclature proposed by MACHOLD et al. (37) will be used but for comparison ANDERSON'S nomenclature (2) is given in parenthesis when appropriate.

\section{MATERIALS AND METHODS}

\subsection{Thylakoids}

Mesophyll and bundle sheath thylakoids were obtained from enzymatically separated mesophyll protoplasts and bundle sheath strands, respectively, as described earlier (13). PSI-1 10 particles were prepared as in (40).

PSIl activity as DCMU sensitive DCPIP photoreduction was determined following the rate of decrease in absorbance at $575 \mathrm{~nm}$ using 1,5-diphenylcarbazide $(0.5 \mathrm{mM})$ as the electron donor.

\subsection{Spectroscopy}

Absorbance spectra were taken with an Aminco DW2a spectrophotometer. Thylakoid membranes were suspended in $5 \mathrm{~mm}$-Tricine $\mathrm{NaOH} \mathrm{pH}(8.0)$ so that the maximum absorbance in the red peak was between 0.5 and 0.8 . Difference spectra were taken after adjusting the two samples to the same absorbance value at the red peak. For measurements at $77 \mathrm{~K}$ the membranes were suspended in buffer containing $60 \%$ glycerol and the sample was placed in liquid nitrogen. The fluorescence spectra were taken at $77 \mathrm{~K}$ using a fiber optic system (Applied Photophysics, London, England) as in (52). The chl concentration was $50 \mu \mathrm{g} \cdot \mathrm{ml}^{-1}$.

Circular dichroism spectra were taken with a Roussel-Jouen Dichrograph III and the optic pathlength was $2 \mathrm{~mm}$.

\subsection{Electrophoresis}

For nondenaturing tube SDS-PAGE, membranes stored at $-80^{\circ} \mathrm{C}$, were washed two times with $2 \mathrm{mM}$-Tris-maleate $\mathrm{pH} 7.0$ and solubilized with octyl- $\beta$-D-glucoside (Sigma). The detergent to chl ratio was $20: 1(w / w)$. The chl concentration was $0.8 \mathrm{mg} \cdot \mathrm{ml}^{-1}$. Electrophoresis was carried out essentially as described previously (13) but a better resolution was obtained because a $10 \%$ acrylamide resolving gel (acrylamide:bisa-

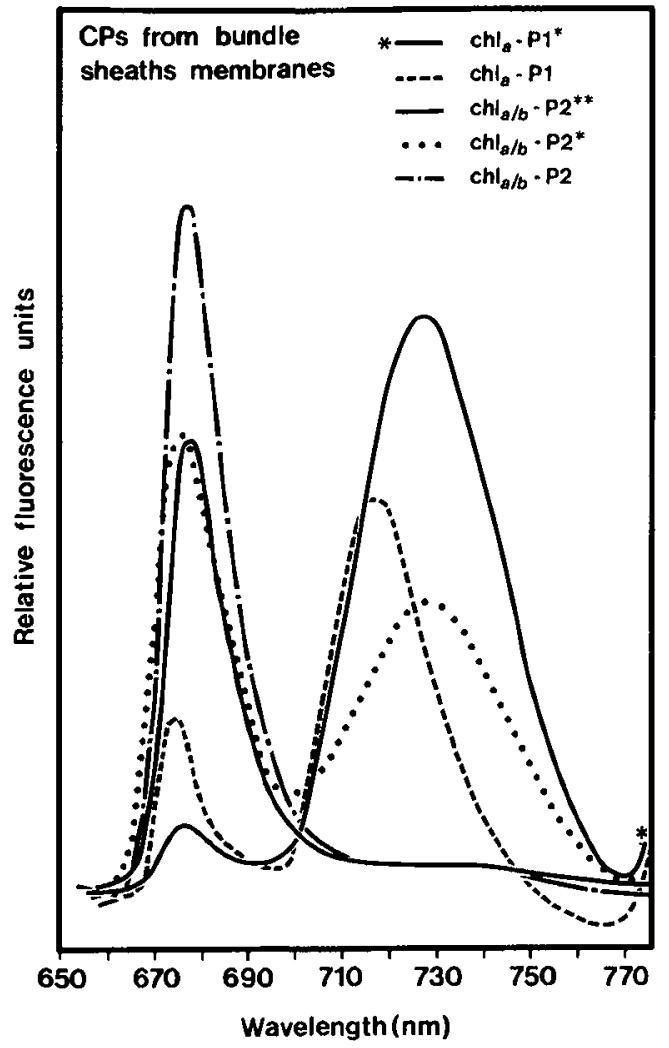

Figure 2. In situ $77 \mathrm{~K}$ fluorescence spectra of CPs from bundle sheath membranes separated by SDSPAGE.

crylamide $=30: 1.05(w / w))$ was used. Green bands were excised from the gel and frozen immediately in liquid nitrogen. The fluorescence emission spectra were recorded in situ as reported in (52). Absorbance spectra from gel slices containing CPs were recorded in situ. Alternatively, gel slices from ten tubes were ground in cold, glass distilled water and eluted overnight at $4{ }^{\circ} \mathrm{C}$. Gel debris were removed by filtering through a $20 \mu \mathrm{m}$ mesh nylon net and centrifuging for $15 \mathrm{~min}$ in an Eppendorf microfuge at $4{ }^{\circ} \mathrm{C}$. In both cases spectra showed the same peak wavelength but spectra from eluted samples showed no light scattering effect. Attempts to elute the CPs with a Triton X-100 containing buffer caused a blue shift of the red peaks.

For the determination of the polypeptide 

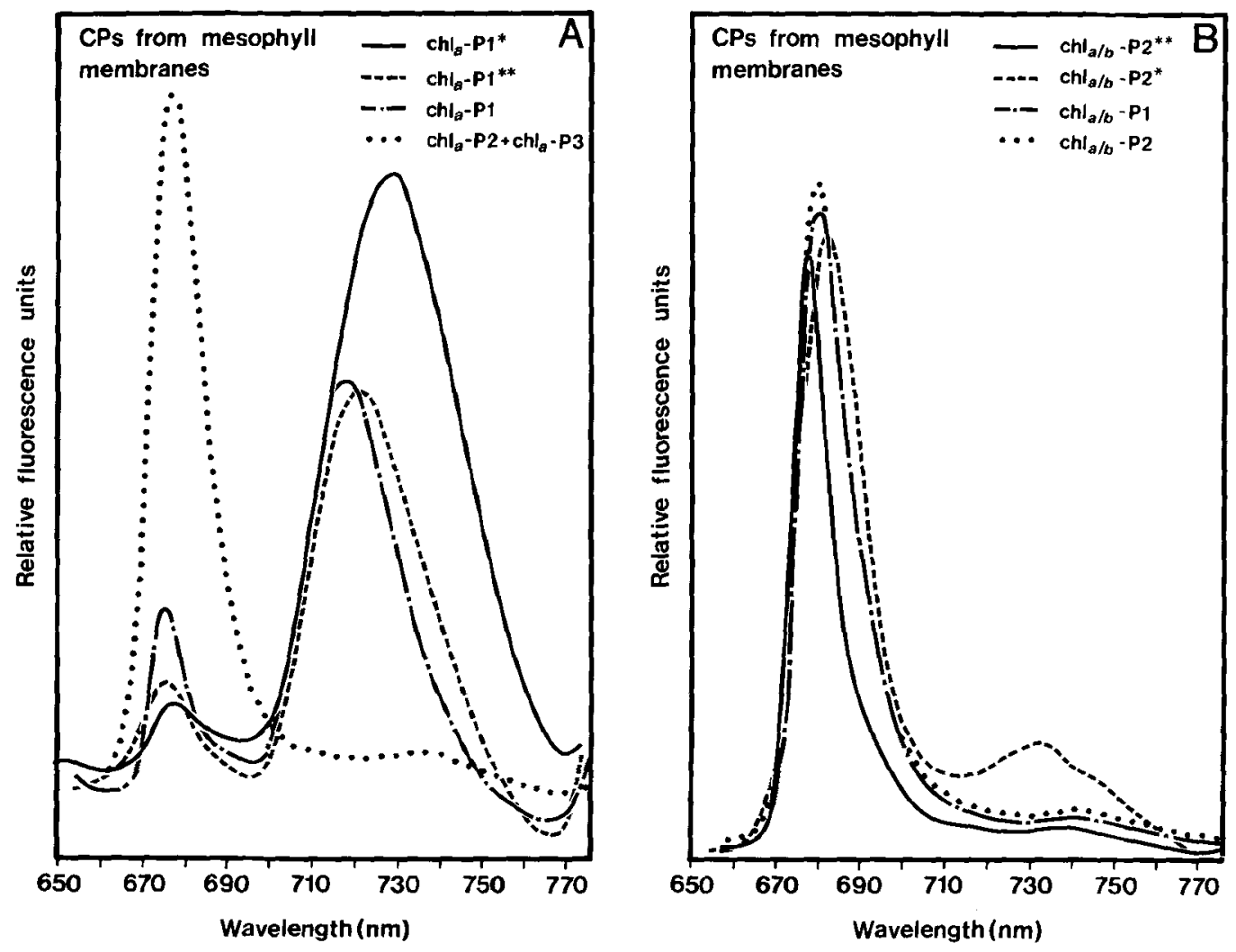

Figure 3. A and B. In situ $77 \mathrm{~K}$ fluorescence spectra of CPs from mesophyll membranes separated by mild SDS-PAGE.

composition, gel slices were cut in small pieces and applied to a $2 \mathrm{~mm}$ thick gel $(20 \times 30 \mathrm{~cm})$ containing $6 \mathrm{M}$-urea. The buffer system used was the number IV described by MACHOLD et al. (37). Gels were stained with Coomassie brilliant blue $\mathrm{R} 250$ and destained as in (37).

Apparent molecular masses were obtained by comparison with the following standards: phosphorylase $b(94 \mathrm{kD})$, bovin serum albumin $(67$ $\mathrm{kD}$ ), ovalbumin (43 kD), carbonic anhydrase $(30 \mathrm{kD})$, trypsin inhibitor $(20.1 \mathrm{kD}), \alpha$-lactosidase (14.4 kD).

The chlorophyll concentration was determined as described by ARNON (10).

\section{RESULTS}

\subsection{Separation and characterization of chloro- phyll-proteins}

In Figure 1, the unstained tube gels of bundle sheath and mesophyll thylakoids after nondenaturing SDS-PAGE are compared. Differences in the CP patterns are evident particularly in the middle region of the gel. Bundle sheath thylakoids lack two apple-green bands $\left(\mathrm{Chl}_{a}-\mathrm{P} 2\right.$ and $\mathrm{Chl}_{\alpha}-\mathrm{P} 3$ ) and the amount of chl in the $\mathrm{Chl}_{a / b^{-}}$ $\mathrm{P} 2^{* *}$ band is markedly reduced. In contrast the $\mathrm{Ch}_{a / b}-\mathrm{P} 2^{*}$ band, reported to be an oligomer of $\mathrm{Ch}_{a / b}-\mathrm{P} 2$, is not reduced in the gels from bundle sheath membranes, suggesting that $\mathrm{Chl}_{a / b}-\mathrm{P} 2^{*}$ is different from $\mathrm{Ch}_{a, b}-\mathrm{P} 2^{* *}$. This is supported by the following experiment. Both types of thylakoids were solubilized with low amounts of SDS (chl:SDS $=4: 1$ ) but in the presence of $5 \mathrm{mM}$ EDTA. This treatment dissociates both $\mathrm{ChI}_{a}$ $\mathrm{P1}^{*}$ and $\mathrm{Ch}_{a / b}-\mathrm{P} 2^{* *}$, they disappear while the intensity of $\mathrm{Chl}_{a}-\mathrm{P} 1$ and $\mathrm{Chl}_{a / b}-\mathrm{P} 2$ increases. There was more $\mathrm{Chl}_{a h b}-\mathrm{P} 2^{*}$ after solubilization in the presence of EDTA (derived from $\mathrm{Chl}_{a}$ P1*). A decrease would have been expected if 


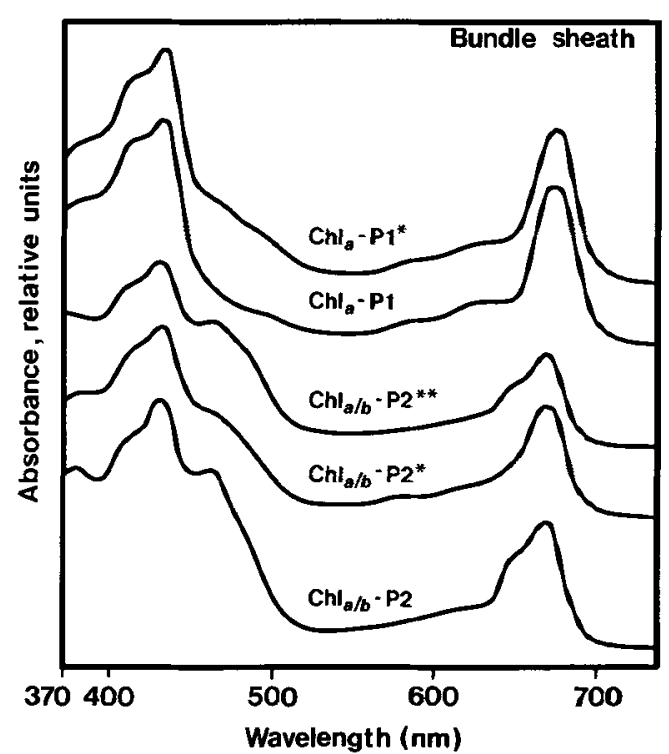

Figure 4. Room temperature absorbance spectra of CPs from bundle sheath thylakoids, eluted from gel slices.

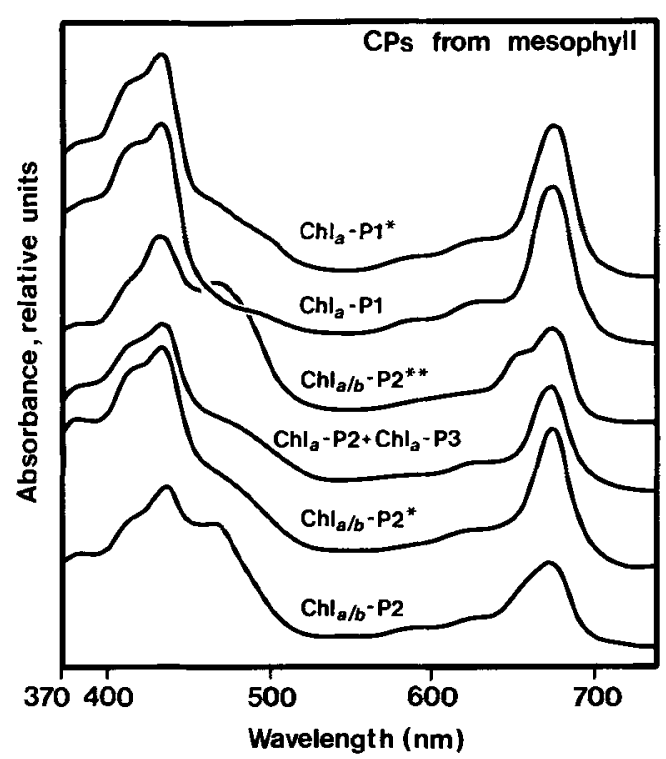

Figure 5. Room temperature absorbance spectra of CPs from mesophyll thylakoids, eluted from gel slices.

Table I.

Summary of the characteristics of the CPs from bundle sheath and mesophyll thylakoids of Zea mays

\begin{tabular}{|c|c|c|c|c|c|}
\hline Mesophyll & $\operatorname{chl} b$ & $\begin{array}{l}\text { absorption } \\
\text { maximum }(\mathrm{nm})\end{array}$ & $\mathrm{F} 1$ & F3 & polypeptides \\
\hline $\mathrm{Chl}_{a}-\mathrm{Pl} *(\mathrm{Cpla})$ & \pm & 675 & 680 & 731 & $\begin{array}{l}\mathrm{RCI}+\mathrm{A}, \mathrm{B}, \mathrm{C}, \mathrm{D}, \mathrm{E}+ \\
\mathrm{I}, \mathrm{L}, \mathrm{M}, \mathrm{N}, \mathrm{O}, \mathrm{P}, \mathrm{Q}\end{array}$ \\
\hline $\mathrm{Chl}_{\alpha}-\mathrm{Pl}$ (CPI) & - & 676 & 678 & 720 & $\mathrm{RCI}$ \\
\hline $\mathrm{Ch} \mathrm{l}_{u / 1}-\mathrm{P} 2^{* *}$ (LHCP1) & +++ & 673 & 678 & - & $\mathrm{F}, \mathrm{G}, \mathrm{H}, \mathbf{R}$ \\
\hline $\begin{array}{l}\mathrm{Chl}_{a}-\mathrm{P} 2+ \\
\mathrm{Chl}_{a}-\mathrm{P} 3 \text { (cpas) }\end{array}$ & \pm & 673 & 681 & - & $\mathrm{Chl}_{a}-\mathrm{AP} 2+\mathrm{Chl}_{a}-\mathrm{AP} 3$ \\
\hline $\begin{array}{l}\mathrm{Chl}_{a / 1}-\mathrm{P} 3 \\
\left(\mathrm{P} 2^{*}, \mathrm{LHCP} 2\right)\end{array}$ & + & 673 & 683 & 732 & $\mathrm{Chl}_{a}-\mathrm{AP} 3+\mathrm{B}, \mathrm{C}, \mathrm{D}$ \\
\hline $\mathrm{Chl}_{u / h}, \mathrm{P} 2$ (LHCP3) & +++ & 671 & 681 & - & $\mathrm{F}, \mathrm{G}, \mathrm{H},(\mathrm{E} ?)$ \\
\hline \multicolumn{6}{|l|}{ Bundle sheath } \\
\hline $\mathrm{Chl}_{a}-\mathrm{Pl} \mathbf{l}^{*}(\mathrm{CP} \mid \mathrm{a})$ & \pm & 675 & 680 & 730 & $\begin{array}{l}\mathrm{RCI}+\mathrm{A}, \mathrm{B}, \mathrm{C}, \mathrm{D}, \mathrm{E}+ \\
\mathrm{I}, \mathrm{L}, \mathrm{M}, \mathrm{N}, \mathrm{O}, \mathrm{P}, \mathrm{Q}\end{array}$ \\
\hline $\mathrm{Chl}_{a}-\mathrm{Pl}(\mathrm{CPl})$ & - & 676 & 678 & 721 & $\mathrm{RCI}$ \\
\hline $\mathrm{Chl}_{a / h}-\mathrm{P} 2^{* *}(\mathrm{LHCPI})$ & +++ & 672 & 679 & - & $\mathrm{F}, \mathrm{G}, \mathrm{H}, \mathrm{R}$ \\
\hline $\mathrm{Chl}_{a / h}-\mathrm{P} 3\left(\mathrm{P} 2^{*}, \mathrm{LHCP} 2\right)$ & + & 673 & 679 & 732 & B,C,D \\
\hline $\mathrm{Chl}_{a / h}-\mathrm{P} 2(\mathrm{LHCP} 3)$ & +++ & 671 & 680 & - & $\mathrm{F}, \mathrm{G}, \mathrm{H},(\mathrm{E}) ?$ \\
\hline
\end{tabular}

Apparent molecular masses of polypeptides found in CPs of bundle sheath and mesophyll thylakoids obtained by comparison with standard proteins as in Materials and Methods (2.3):

$\begin{array}{llllll}\mathrm{RCI} & =110 \mathrm{kD} & \mathrm{C}=22.5 \mathrm{kD} & \mathrm{H}=26.5 \mathrm{kD} & \mathrm{O}=8.8 \mathrm{kD} \\ \mathrm{Chl}_{\alpha}-\mathrm{AP2} & =48 \mathrm{kD} & \mathrm{D}=21 \mathrm{kD} & \mathrm{I}=18.9 \mathrm{kD} & \mathrm{P}=6.7 \mathrm{kD} \\ \mathrm{Chl}_{\alpha}-\mathrm{AP3} & =42 \mathrm{kD} & \mathrm{E}=20.6 \mathrm{kD} & \mathrm{L}=10.9 \mathrm{kD} & \mathrm{Q}=6.2 \mathrm{kD} \\ \mathrm{A} & =24.9 \mathrm{kD} & \mathrm{F}=28.8 \mathrm{kD} & \mathrm{M}=10.4 \mathrm{kD} & \mathrm{R}=7.8 \mathrm{kD} \\ \mathrm{B} & =23.9 \mathrm{kD} & \mathrm{G}=27.6 \mathrm{kD} & \mathrm{N}=9.4 \mathrm{kD} & \end{array}$




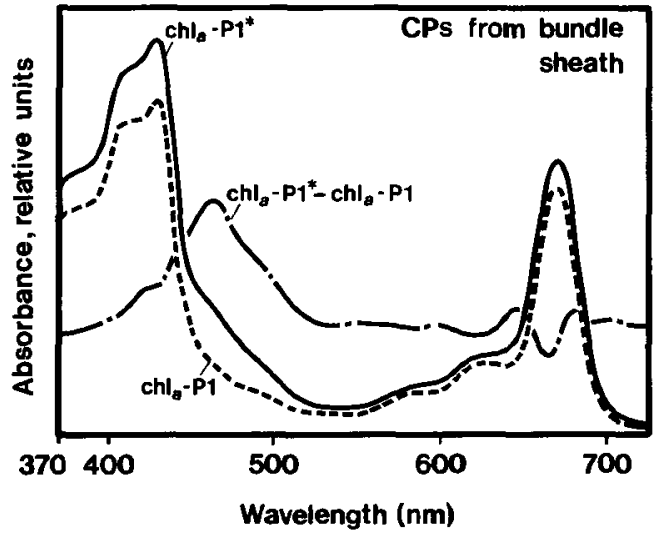

Figure 6. Room temperature absorbance spectra of $\mathrm{Chl}_{\alpha}-\mathrm{Pl} l^{*}, \mathrm{Chl}_{a}-\mathrm{Pl}$ and difference spectrum $\mathrm{Chl}_{\alpha}-\mathrm{P} 1^{*}$ minus $\mathrm{Chl}_{a}-\mathrm{Pl}$.

$\mathrm{Ch}_{u / t}-\mathrm{P} 2^{*}$ is an oligomer of $\mathrm{Ch}_{a / t h}-\mathrm{P} 2$.

$77 \mathrm{~K}$ fluorescence emission spectra of gel slices confirm that $\mathrm{Chl}_{a / b}-\mathrm{P} 2^{*}$ is different from the other $\operatorname{chl} a / b$ binding CPs (Figure 2). In the bundle sheath thylakoids this CP shows a long

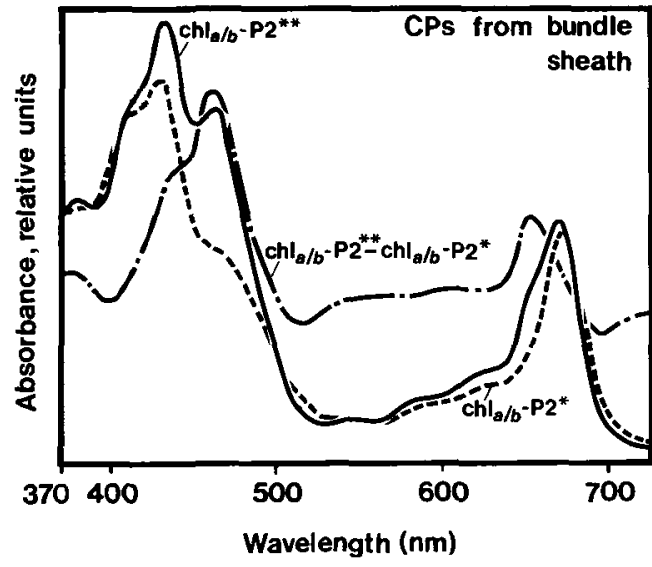

Figure 7. Room temperature absorbance spectra of

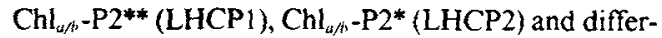
ence spectrum $\mathrm{Ch}_{a / t}-\mathrm{P} 2^{* *}$ minus $\mathrm{Ch}_{a / s}-\mathrm{P} 2^{*}$.

wavelength fluorescence emission peak at 732 $\mathrm{nm}$. The corresponding green band from mesophyll thylakoids show mainly the short wavelength emission $(683 \mathrm{~nm})$ and a minor peak at $732 \mathrm{~nm}$ (Figure 3B). In the mesophyll sample it

Figure 8. Re-electrophoresis of CPs from bundle sheath and mesophyll thylakoids under denaturing conditions. CPs were separated by nondenaturing SDS-PAGE at $4{ }^{\circ} \mathrm{C}$ as shown in Figure 1. Gel slices containing CPs were cut into small pieces and applied to the slots of the present gel without other treatment. Thylakoid samples were solubilized in $150 \mathrm{~mm}$-Tris-sulphate, $1 \% \mathrm{SDS}, 6 \mathrm{M}$-urea and centrifuged for $15 \mathrm{~min}$ in an Eppendorf microfuge. $30 \mu \mathrm{g}$ of chl was applied to each slot.

1: mesophyll thylakoids

2: re-electrophoresis $\mathrm{Chl}_{a / h}-\mathrm{P} 2$

3: $\quad$. $\quad \mathrm{Chl}_{a / h}-\mathrm{Pl}$

4: $\quad$ a $\quad \mathrm{Chl}_{a f b}-\mathrm{P} 3\left(\mathbf{P} 2^{*}\right)+\mathrm{Chl}_{a}-\mathrm{P} 3$

5: $\quad \cdots \quad \mathrm{Chl}_{a}-\mathrm{P} 2$

6: “ $\quad \mathrm{Chl}_{a / h}-\mathrm{P2}$ **

7: “ $\quad \mathrm{Chl}_{a}-\mathrm{PI}$

8: $\quad$ “ $\quad \mathrm{Chl}_{a}-\mathrm{Pl}^{*}$ a (band migrating between $\mathrm{Chl}_{a}-\mathrm{Pl}$ and $\mathrm{Chl}_{a}-\mathrm{Pl} 1^{*}$ )

9: “ $\quad \mathrm{Chl}_{a}-\mathrm{Pl}$ *

10: mesophyll thylakoids.

11: Mol.wt. standards as in Materials and Methods (2.3).

12: bundle sheath thylakoids

13: re-electrophoresis of $\mathrm{Chl}_{a / t}-\mathrm{P} 2$

14: " $\quad \mathrm{Chl}_{a / t}-\mathrm{P} 2$

15: $\quad$ " $\quad \mathrm{Chl}_{a / h}-\mathrm{P} 3\left(=\mathrm{P}^{*}\right)$

16: " " $\quad \mathrm{Chl}_{a t s}-\mathrm{P} 2 * *$

17: “ $\quad \mathrm{Chl}_{a}-\mathrm{P1}$

18: " $\quad \mathrm{Chl}_{a}-\mathrm{Pl}^{*}$

19: bundle sheath thylakoids

20: mesophyll thylakoids

The gel was a $10-20 \%$ acrylamide gradient gel including 6 m-urea. 


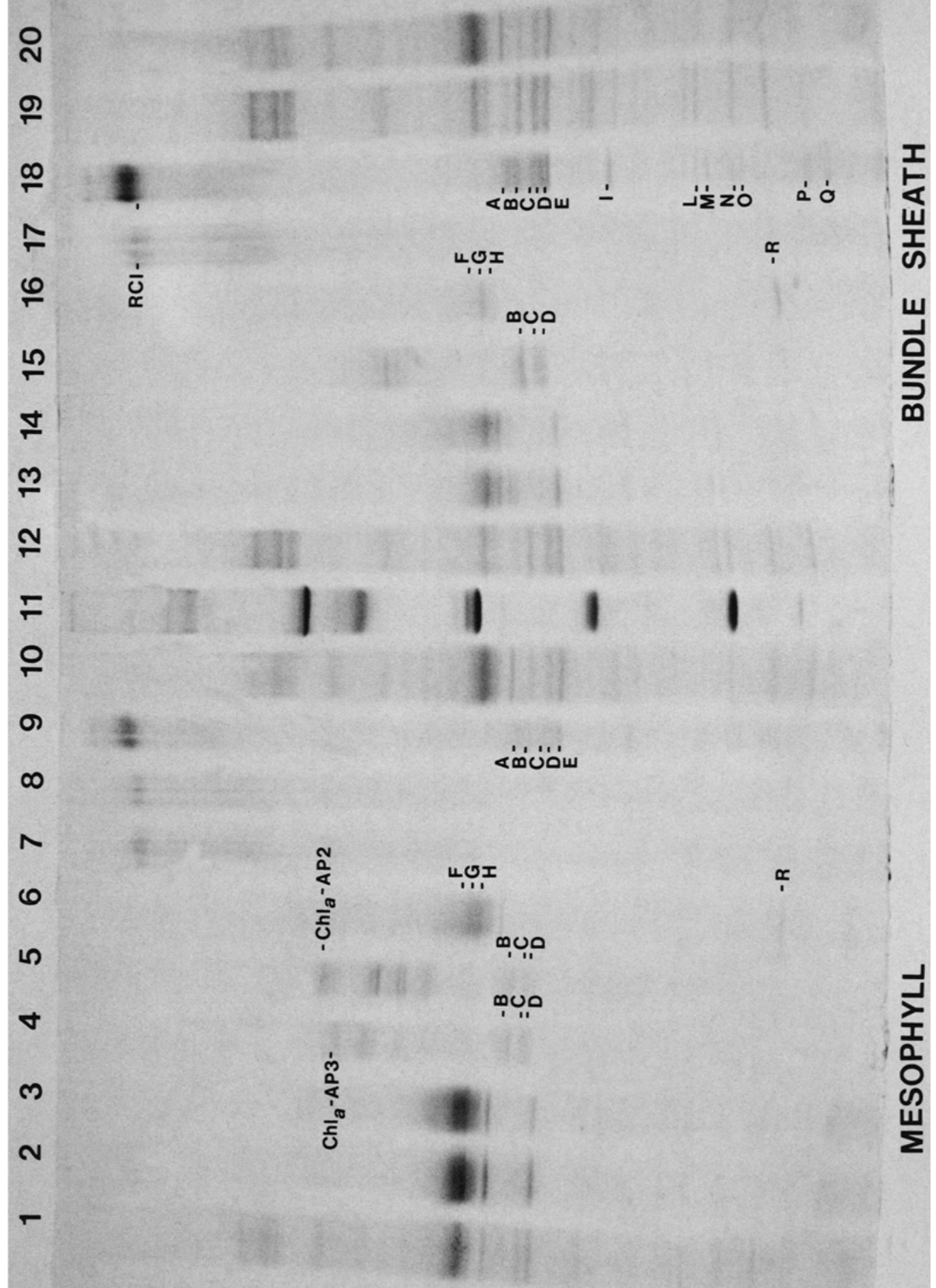




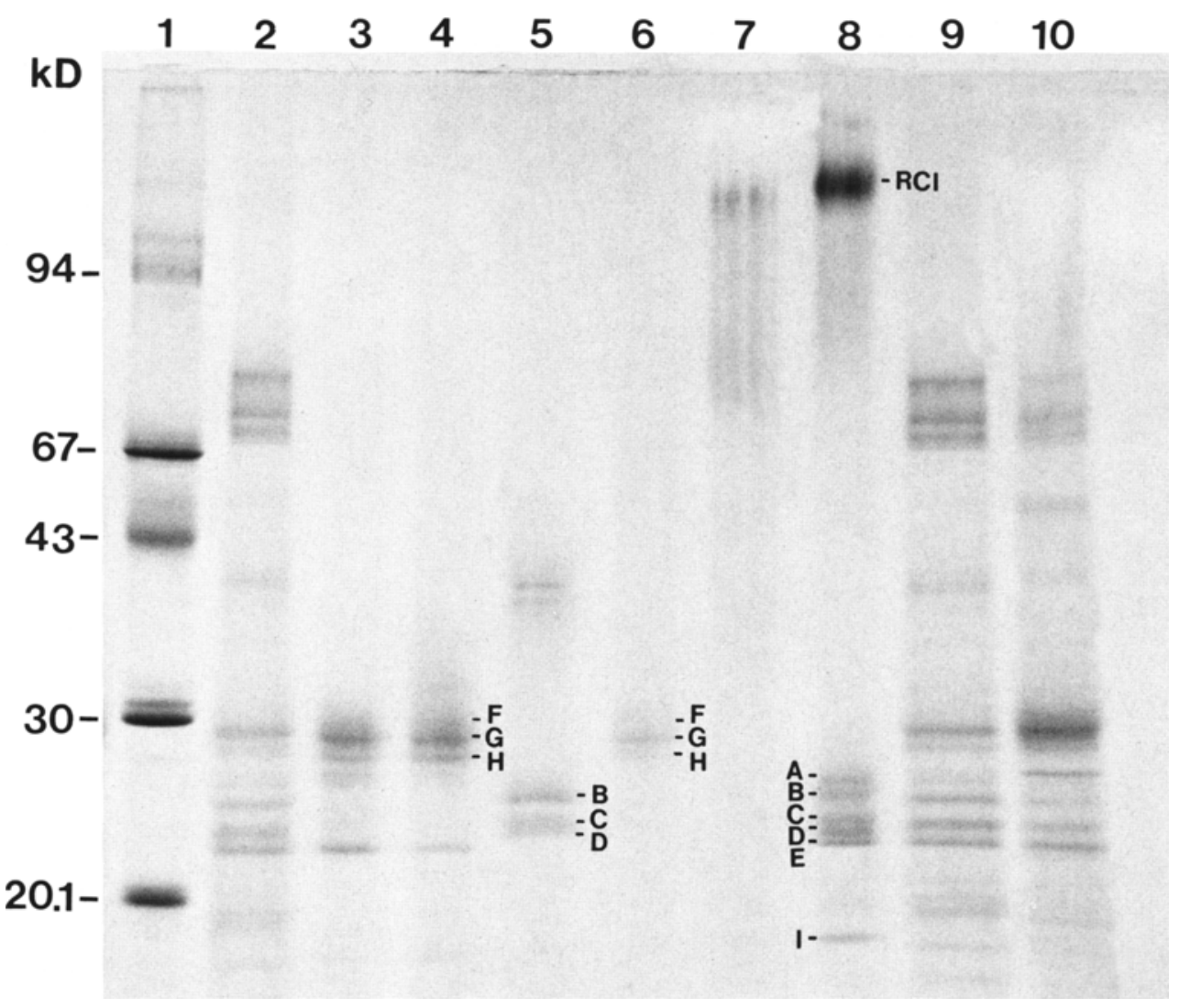

Figure 9. Re-electrophoresis of CPs from bundle sheath thylakoids.

1: Mol.wt. standards

2: bundle sheath thylakoids

3: re-electrophoresis of $\mathrm{Chl}_{\alpha / \gamma}-\mathrm{P} 2$

4: $\quad$ " $\quad \mathrm{Chl}_{\alpha / \mu}-\mathrm{P} 2$

5: $\quad$ " $\quad \mathrm{Chl}_{\mu / t}-\mathrm{P} 3\left(=\mathrm{P} 2^{*}\right)$

6: “ $\quad \mathrm{Chl}_{u / h}-\mathrm{P} 2^{* *}$

7: “ $\quad \mathrm{Chl}_{a}-\mathrm{Pl}$

8: “ $\quad \mathrm{Chl}_{a}-\mathrm{P} 1^{*}$

9: bundle sheath thylakoids

10: mesophyll thylakoids.

is not possible to cut out the band containing $\mathrm{Chl}_{a / b}-\mathrm{P} 2 *$ without contamination from $\mathrm{Chl}_{a}-\mathrm{P} 3$ (which fluoresces at $683 \mathrm{~nm}$ ), while this CP is absent in bundle sheath thylakoids. This leads to an excess of fluorescence at $683 \mathrm{~nm}$ and explains the difference between the emission spectra from the bands in the two types of plastids.

The prominent presence of $\mathrm{Ch}_{\alpha / h}-\mathrm{P2}^{*}$ in bundle sheath thylakoids intimates that it ac- tually acts as a PSI light harvesting chl $a / b$ protein or LHCI.

In both mesophyll and bundle sheath samples, two other CPs show a long wavelength (>700nm) fluorescence emission: the $\mathrm{Chl}_{a}-\mathrm{Pl}^{*}$ at $730 \mathrm{~nm}$ and the $\mathrm{Chl}_{a}-\mathrm{P} 1$ at $720 \mathrm{~nm}$ (Figures 2 and $3 \mathrm{~A}) . \mathrm{Chl}_{a, h}-\mathrm{Pl}, \mathrm{Chl}_{a / h}-\mathrm{P} 2$ and $\mathrm{Chl}_{a / b}-\mathrm{P} 2^{* *}$ had only an intense emission at $680 \mathrm{~nm}$ (Figures 2 and 3B). 


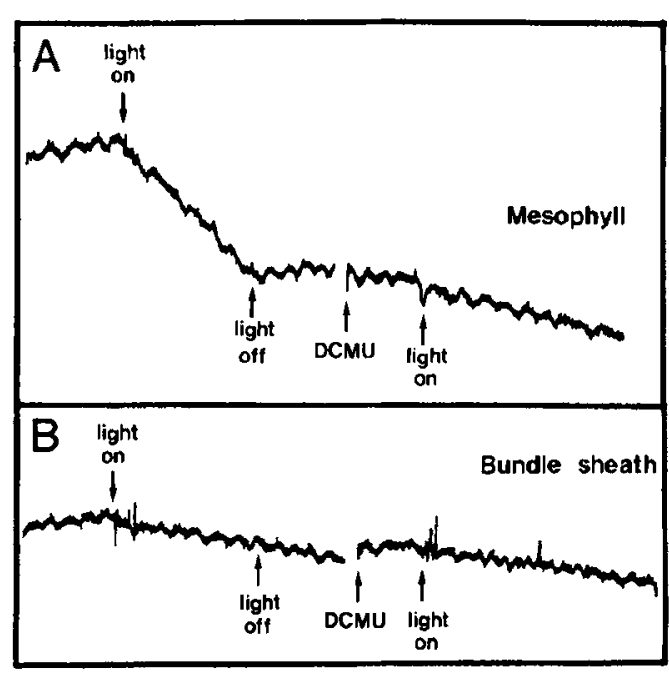

Figure 10. Change in absorbance at $575 \mathrm{~nm}$ when monitoring the light induced DCPIP photoreduction with 1,5-diphenylcarbazide as electron donor. The actinic light was filtered through a red filter Corning 2-64. A blue filter Corning 4-96 was inserted between the sample and the photomultiplier. Measurable PSII activity is only present in the mesophyll sample. The very small absorbance change observed with the bundle sheath sample was not sensitive to DCMU.

Absorbance spectra of CPs from bundle sheath and mesophyll thylakoids are shown in Figures 4 and 5. Table I summarizes the absorption and fluorescence maxima. Absorption spectra from corresponding CPs from the two types of membranes are similar. The spectra of the two PSI related CPs $\left(\mathrm{Chl}_{a}-\mathrm{Pl}\right.$ and $\left.\mathrm{Chl}_{a}-\mathrm{P} 1^{*}\right)$ showed mainly the chl $a$ contribution. The difference spectrum $\mathrm{Chl}_{a}-\mathrm{Pl}$ * minus $\mathrm{Chl}_{a}-\mathrm{Pl}$ showed that the former contained chl $b$ (peak at $652 \mathrm{~nm}$ ) and more carotenoids (broad peak at 460-480 nm (Figure 6)). $\mathrm{Chl}_{a}-\mathrm{P} 2$ and $\mathrm{Chl}_{a}-\mathrm{P} 3$ are present only in the mesophyll membrane, and were cut out and eluted together from the gel. Their absorption spectra show the chl $a$ content. A shoulder at $472 \mathrm{~nm}$ is probably due to contamination with $\mathrm{Chl}_{a / h}-\mathrm{P} 2^{*}$.

The spectra of the other CPs reveal them to contain both chl $a$ and $b . \mathrm{Chl}_{a / b}-\mathrm{P} 1, \mathrm{Chl}_{a / b}-\mathrm{P} 2$ and $\mathrm{Chl}_{\alpha, h}-\mathrm{P} 2 * *$ have significantly more chl $b$ than $\mathrm{Chl}_{a r t}-\mathrm{P} 2^{*}$ as clearly shown by the difference spectrum $\mathrm{Ch}_{a / b}-\mathrm{P} 2^{* *}$ minus $\mathrm{Chl}_{a / b}-\mathbf{P} 2^{*}$ (Figure 7).

\subsection{Polypeptide composition of the chloro-} phyll-proteins

The green bands cut from nondenaturing tube gels were re-electrophoresed in the presence of 6 $M$-urea and the polypeptide composition of the CPs was determined. In both bundle sheath and mesophyll samples, re-electrophoresis of $\mathrm{Chl}_{a}$ $P 1^{*}$ gave rise to a $110 \mathrm{kD}$ band and to five polypeptides with apparent molecular weight between 20 and $25 \mathrm{kD}$ (polypeptides A, B, C, D, E in Figures 8 and 9). In addition, seven polypeptides (I, L, M, N, O, P, Q) with molecular weights between 18 and $6 \mathrm{kD}$ are reproducibly observed. The polypeptides $\mathrm{B}, \mathrm{C}$ and $\mathrm{D}$ are also generated upon the re-electrophoresis of $\mathrm{Chl}_{a / b}-\mathrm{P} 2^{*}$ from bundle sheath thylakoids (Figure 9). Thus the $732 \mathrm{~nm}$ emission is specifically found in the presence of the bands $B, C$ and $D$.

Polypeptides B, C and D were likewise formed upon re-electrophoresis of $\mathrm{Chl}_{a / b}-\mathrm{P} 2 *$ from mesophyll thylakoids in agreement with its minor emission peak at $732 \mathrm{~nm}$. $\mathrm{Chl}_{a / b}-\mathrm{P} 2^{* *}$ from both bundle sheath and mesophyll contains three polypeptides (F, G and $\mathrm{H}$ in Figures 8 and 9) with molecular masses between 26 and $29 \mathrm{kD}$. They were also present in $\mathrm{Chl}_{a / h}-\mathrm{Pl}$ and $\mathrm{Chl}_{a / h}$ $\mathrm{P} 2$ which fluoresce at about $680 \mathrm{~nm}$. $\mathrm{Chl}_{a / b}$ P2**, $\mathrm{Chl}_{a / h}-\mathrm{P} 1$ and $\mathrm{Chl}_{a / s}-\mathrm{P} 2$ showed a very similar polypeptide composition as well as similar fluorescence and absorption spectra (Figures 9, 3A and 3B). Nevertheless, $\mathrm{Chl}_{\alpha / h}-\mathrm{P} 2^{* *}$ shows a low molecular weight component (polypeptide $\mathrm{R}$, about $7-8 \mathrm{kD}$ ) that is not present in the high mobility forms of $\mathrm{Chl}_{\alpha / h}-\mathrm{P} 1$ and $\mathrm{Chl}_{\alpha / h}-\mathrm{P} 2$ (Figure 8). $\mathrm{Ch}_{a / h}-\mathrm{P} 1$ seems to differ from $\mathrm{Ch}_{a / b}-\mathrm{P} 2$ mainly by the chl to protein ratio. The staining intensities of the polypeptides $F, G$ and $H$ (Figure 8) upon re-electrophoresis of $\mathrm{Chl}_{a / h}-\mathrm{Pl}$ and $\mathrm{Chl}_{a / 1}-\mathrm{P} 2$ are the same in spite of the fact that the amount of the chl in $\mathrm{Chl}_{\alpha / b}-\mathrm{P} 1$ gel slices was much less than in those containing $\mathrm{Chl}_{a / b}-\mathrm{P} 2$.

The $720 \mathrm{~nm}$ emission is present only in $\mathrm{Chl}_{a}$-P1 preparations. When analysed by urea gel electrophoresis this $\mathrm{CP}$ is seen to consist of the $110 \mathrm{kD}$ reaction centre or its apoprotein of $67 \mathrm{kD}$. Therefore, chl $a$, when associated with the $67 \mathrm{kD}$ protein, fluoresces at $720 \mathrm{~nm}$. $\mathrm{Chl}_{a / b}$ $\mathrm{P} 1, \mathrm{Chl}_{\alpha / h}-\mathrm{P} 2, \mathrm{Ch}_{\alpha / h}-\mathrm{P} 2^{* *}, \mathrm{Chl}_{a}-\mathrm{P} 2$ and $\mathrm{Chl}_{a}-\mathrm{P} 3$ show very similar fluorescence emissions between 678 and 683 when prepared by mild 


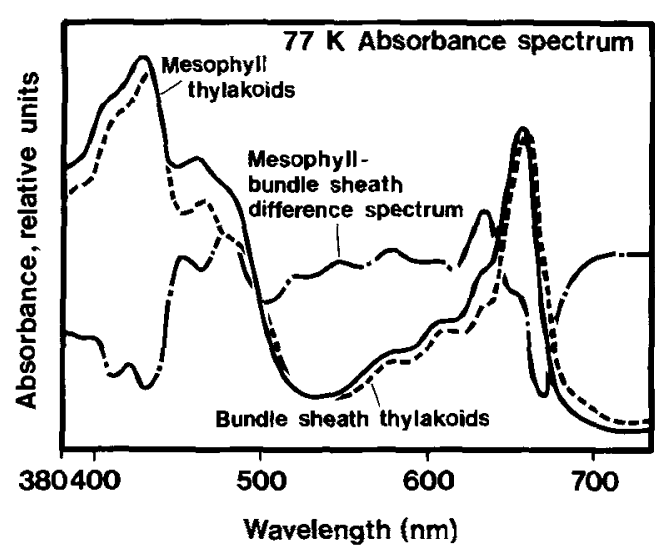

Figure 11. $77 \mathrm{~K}$ absorption spectrum of mesophyll and bundle sheath membranes. The samples were adjusted to the same absorbance $(0.8)$ at the red peak. Other conditions in Material and Methods (2.2).

electrophoresis (with little detergent and short time at $4^{\circ} \mathrm{C}$ ). It was not possible to correlate the $77 \mathrm{~K}$ fluorescence emission at this wavelength with a particular polypeptide composition after separation of the CPs by this method.

\subsection{Spectral characterization of the membranes}

The determination of the DCMU sensitive light induced DCPIP reduction with diphenylcarbazide as electron donor shows that PSII activity is restricted to mesophyll membranes (Figure 10).

When the absorbance spectra of the two types of membranes were compared (Figure 11), those from bundle sheaths had slightly different absorption maxima at the red peak, showing a longer wavelength absorption than mesophyll membranes ( 676.5 against $675.5 \mathrm{~nm}$ ). The different heights of the peaks at 651 and $472 \mathrm{~nm}$ in the $77 \mathrm{~K}$ spectra indicate less chl $b$ in the bundle sheath membranes. The difference spectrum of mesophyll minus bundle sheath thylakoids at 77 $\mathrm{K}$ confirms these findings and in addition identifies a $687 \mathrm{~nm}$ absorption component which is prominent in the bundle sheath thylakoids (Figure 11). The difference spectrum also visualizes the higher carotenoid content of mesophyll membranes than that of bundle sheath thylakoids (488 $\mathrm{nm}$ peak).

As the principal difference between mesophyll and bundle sheath chloroplast membranes is the lack of PSIl in the latter, a greater contribution of PSI to the absorbance spectrum of bundle sheath membranes is expected. To check the hypothesis that the $687 \mathrm{~nm}$ absorption component is associated with PSI, a PSI-110 preparation according to MULLET (40) was examined.

The absorbance spectrum and the $77 \mathrm{~K}$ fluorescence emission spectrum are given in Figures $12 \mathrm{~A}$ and $\mathrm{B}$. The circular dichroism spectrum (Figure 12C) resolves a major negative signal at $687 \mathrm{~nm}$ and positive signals at $673 \mathrm{~nm}, 503 \mathrm{~nm}$, $443 \mathrm{~nm}$ and a shoulder at $481 \mathrm{~nm}$. The negative signal of chl $b$ at $652 \mathrm{~nm}$ was of low amplitude.

The $77 \mathrm{~K}$ fluorescence emission spectrum of higher plant thylakoids contains three bands, namely at $685 \mathrm{~nm}(\mathrm{~F} 1), 695 \mathrm{~nm}(\mathrm{~F} 2)$ and $735 \mathrm{~nm}$ (F3). The first two are assigned to PSII $(15,50)$ and the long wavelength to PSI (15). When fluorescence was excited with $438 \mathrm{~nm}$ light, the bundle sheath membranes showed a reduced $F 1$ and F2 component compared to mesophyll ones. In particular F2 was hardly detectable in the spectra from bundle sheath thylakoids (Figure 13). These differences in the thylakoid fluorescence spectra between bundle sheath and mesophyll cells have been confirmed under a range of chl concentrations between 10 to 500 $\mu \mathrm{g} \cdot \mathrm{ml}^{-1}$.

The LHCII fluoresces only very weakly in the native membrane even at $77 \mathrm{~K}$, probably due to effective quenching by antenna chl associated with the reaction centre (45). Treatment of the photosynthetic membrane with nondenaturing (45) or sub-solubilizing concentrations (12) of detergents result in a great increase of $F 1$ emission relative to $F 2$ and $F 3$ and a shift of $F 1$ from 685 to $680 \mathrm{~nm}$. This is due to the dissociation of LHCII from PSII reaction centres $(43,44)$. The treatment of mesophyll plastid membranes with $10 \mathrm{mg} \cdot \mathrm{ml}^{-1}$ octylglucoside at a chl concentration of $50 \mu \mathrm{g} \cdot \mathrm{ml}^{-1}$ leads to an increase in fluorescence at $F 1$ and a shift of the maximum from 685 to $680 \mathrm{~nm}$ (Figure 13B). The same phenomenon was observed in bundle sheath membranes (Figure $13 \mathrm{C}$ ) even though they lack PSII reaction centres. The fluorescence emission at $680 \mathrm{~nm}$ cannot be ascribed to free chl since centrifugation at $48.000 \times \mathrm{g}$ recovered all the $\mathrm{chl}$ in the pellet. 

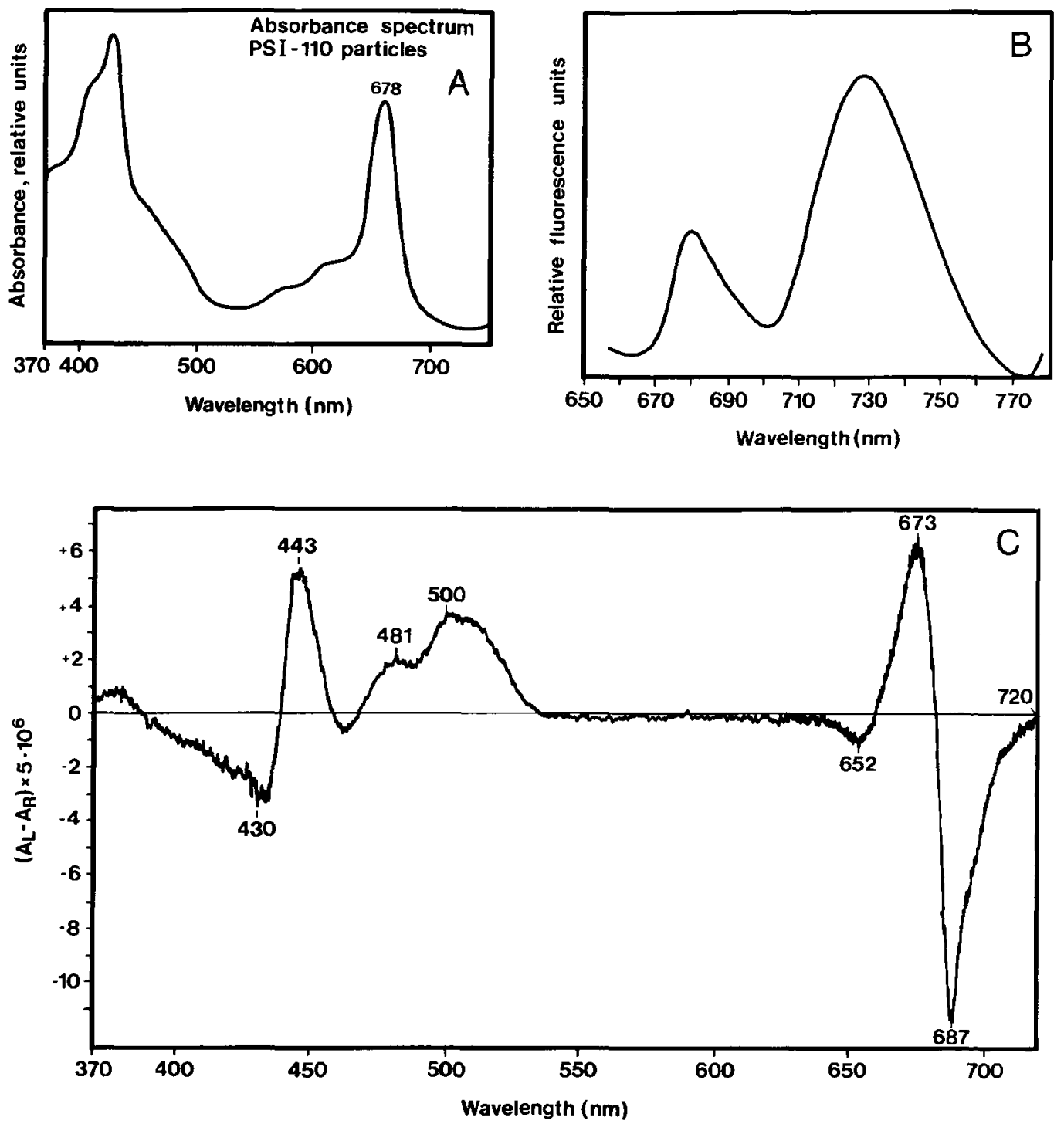

Figure 12. PSI-110 particles prepared as in (40): A) room temperature absorbance spectrum, B) $77 \mathrm{~K}$ fluorescence emission spectrum, C) circular dichroism spectrum. A $2 \mathrm{~mm}$ pathlength cuvette was used giving an absorbance of 0.4 at $678 \mathrm{~nm}$.

Increasing the detergent concentration either to $15 \mathrm{mg} \cdot \mathrm{ml}^{-1}$ SDS or $40 \mathrm{mg} \cdot \mathrm{ml}^{-1}$ octylglucoside gave basically the same results with a higher $\mathrm{F} 1$ peak in mesophyll samples than in bundle sheath ones (Figures 13B and C). At higher concentrations of detergents the $\mathrm{F} 3$ peak disappeared.

To further check the possibility that the detergent treatment makes free chl, $77 \mathrm{~K}$ fluor- escence spectra were recorded from $\mathrm{Chl}_{a / h}-\mathrm{P} 2$ preparations obtained by sucrose gradient centrifugation and resuspended in $0,10,20,40$, $100,200 \mathrm{mg} \cdot \mathrm{ml}^{-1}$ octylglucoside. The chl concentration was $50 \mu \mathrm{g} \cdot \mathrm{ml}^{-1}$. No significant increase was seen in the fluorescence yield at 680 $\mathrm{nm}$, but a 3.5 times increase of fluorescence was seen when $\mathrm{Chl}_{a / h}-\mathrm{P} 2$ was treated with 200 $\mathrm{mg} \cdot \mathrm{ml}^{-1}$ SDS. 

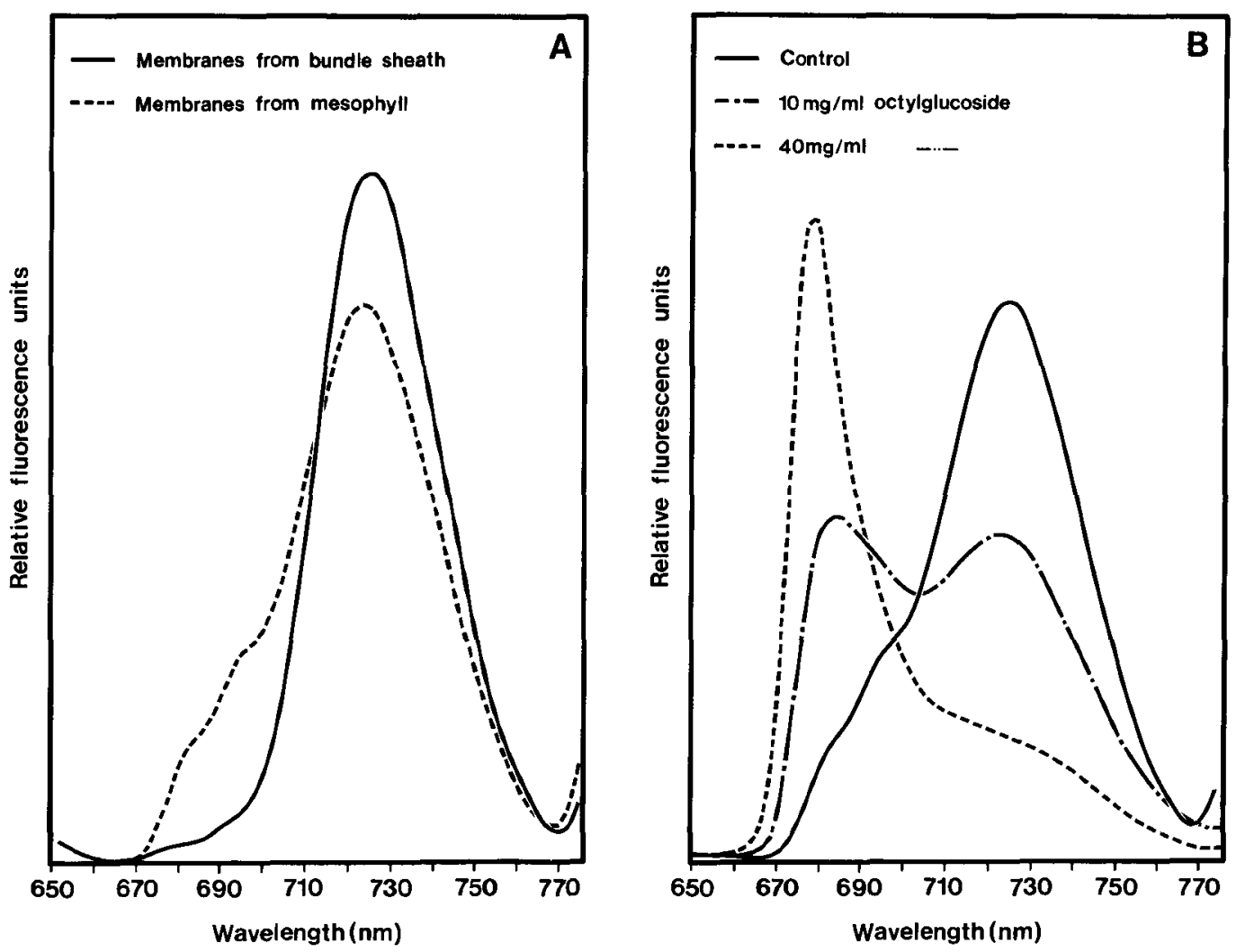

Figure $13.77 \mathrm{~K}$ fluorescence emission spectra of bundle sheath and mesophyll thylakoids before (A) and after (B, C) treatments with two concentrations of detergent. The chl concentration was $50 \mu \mathrm{g} \cdot \mathrm{ml}^{-1}$ and fluorescence excited with blue light defined by a Corning 4-96 filter. Membranes of mesophyll (B) and bundle sheath (C) chloroplasts were diluted to $50 \mu \mathrm{g} \mathrm{chl} \cdot \mathrm{ml}^{-1}$ in a solution with the appropriate amount of detergents and incubated for $1 \mathrm{~min}$ at $4{ }^{\circ} \mathrm{C} .5 \mu \mathrm{l}$ samples were applied to a filter paper disc that was immediately frozen in liquid nitrogen. Other conditions as in Materials and Methods (2.2).

When fluorescence was excited with $472 \mathrm{~nm}$ light, the spectra of both mesophyll and bundle sheath membranes were similar to the spectra obtained with an excitation at $438 \mathrm{~nm}$. This suggests a good energy transfer from chl $b$ binding complexes to the reaction centres in both bundle sheath and mesophyll membranes. In detergent treated bundle sheath and mesophyll chloroplast membranes, fluorescence excitation at $472 \mathrm{~nm}$ gave higher F1 peaks than excitation at $438 \mathrm{~nm}$ indicating that the F1 fluorescent species is LHCII (BASSI, BARBATO, PERUfFo and GenNARI, unpublished results).

\section{DISCUSSION}

The separation method of bundle sheath and mesophyll cells by enzymatic digestion gives a very pure preparation as demonstrated by the activities of carboxylating enzymes, light microscopy, and SDS-PAGE analysis (13). The absence of PSII reaction centres in bundle sheath thylakoids has been demonstrated by the lack of the two PSII chl $a$ binding proteins as well as other polypeptides involved in PSII activity (13). Now it is shown that no DCMU-sensitive DCPIP reduction activity is present in thus prepared bundle sheath thylakoids.

The difference spectrum between mesophyll and bundle sheath thylakoids, shows that chl 


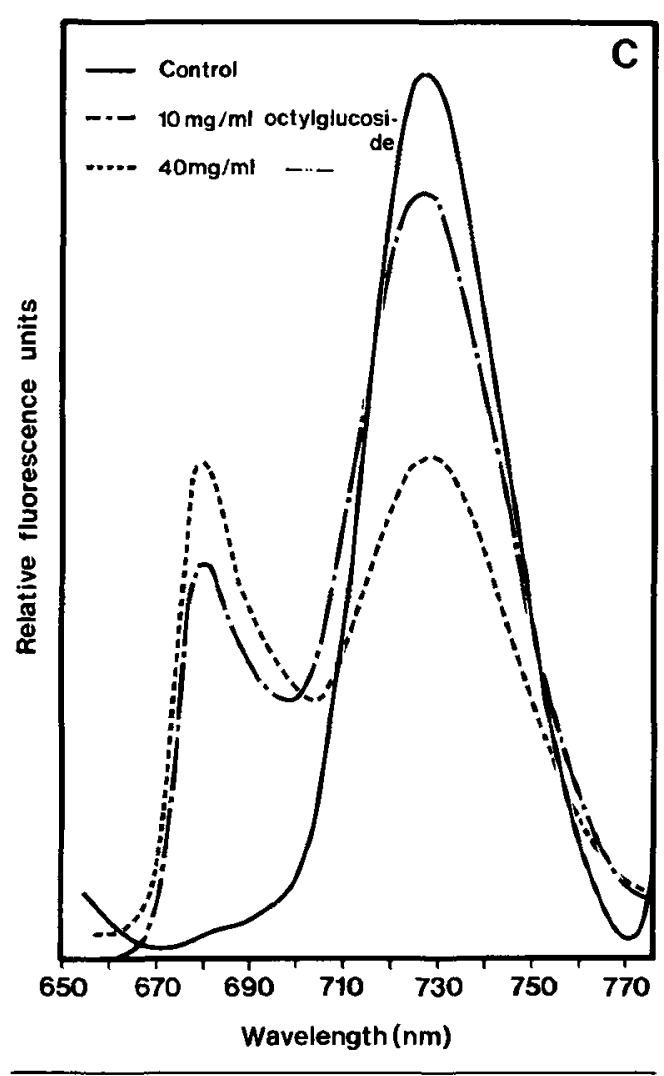

$b$ containing CPs are present in smaller amounts in bundle sheath membranes than in mesophyll thylakoids. On the other hand, bundle sheath membranes have a higher absorbance at wavelengths longer than $675 \mathrm{~nm}$ resulting in a negative peak in the difference spectrum at $687 \mathrm{~nm}$.

This long wavelength absorption is attributed to the PSI complex since the circular dichroism spectrum from a PSI-110 preparation gives an intense negative peak at $687 \mathrm{~nm}$ (Figure 12C). The component absorbing at $687 \mathrm{~nm}$ can probably be attributed to a chl $a$ species belonging to the inner antenna of PSI as it was selectively removed during the preparation of PSI-40 from PSI-65 (Figure 11B in ref. 40). A $687 \mathrm{~nm}$ component was also resolved by computer deconvolution analysis of the $77 \mathrm{~K}$ absorption spectrum of the $\mathrm{Chl}_{a}-\mathrm{Pl}$ (CP1), which in all contained only four components (17). HAWORT et al. (25) separated the PSI-1 10 preparation into PSI-65 and an LHCI component containing a
$21 \mathrm{kD}$ apoprotein and attributed the $686 \mathrm{~nm}$ circular dichroism signal to this component.

The use of mild electophoretic techniques which includes running the gels at low temperature, has greatly increased the recovery of chl in association with proteins. This led to the description of up to $10 \operatorname{CPs}(2,16,26,37)$. This study on mesophyll and bundle sheath CPs confirms the assignment of $\mathrm{Chl}_{a}-\mathrm{P} 2$ and $\mathrm{Chl}_{a}-\mathrm{P} 3$ (cpas) to the PSII $(8,22,27,32,38,55)$ since both of them are the only CPs absent in bundle sheath thylakoids. Previous studies of $\mathrm{chl}_{a}-\mathrm{Pl}{ }^{*}$ have shown the complexity of this component $(5,6,33)$. In this paper it is demonstrated that $\mathrm{Chl}_{u}-\mathrm{Pl}$ and $\mathrm{Chl}_{a}-\mathrm{Pl}{ }^{*}$ represent the PSI reaction centre $(110 \mathrm{kD}$ protein) and a complex of it with $\mathrm{Chl}_{\alpha, t}-\mathrm{P} 2 *$ (LHCP2) and additional lower molecular weight polypeptides, respectively.

The previous suggestion that $\mathrm{Ch}_{a / b}-\mathrm{P} 2 *$ (LHCP2) is a multimer of $\mathrm{Chl}_{a / b}-\mathrm{P} 2$ (LHCP3) $(2,5,37,55)$ is no longer tenable. The $\mathrm{Chl}_{\alpha, h}-\mathrm{P} 2^{*}$ is therefore named $\mathrm{Chl}_{a / h}-\mathrm{P} 3$ and is considered a component of LHCI and not of LHCII because the latter does not contain the polypeptides B, $\mathrm{C}$ and $\mathrm{D}$. The $77 \mathrm{~K}$ fluorescence emission at $732 \mathrm{~nm}$ and the high chl $a / b$ ratio likewise are consistent with its origin from PSI. $\mathrm{Chl}_{a / h}-\mathrm{P} 3$ (P2*, LHCP2) is absent in the barley mutant chlorina $f 2(37,55)$ as are the polypeptides $\mathrm{B}$, C, D of the LHCI (42).

Studies including electrophoresis of purified LHCII (18) have given the following results. REMY et al. (48) found $\mathrm{Chl}_{a / b}-\mathrm{P} 2^{* *}$ (LHCP1) and $\mathrm{Ch}_{a / h}-\mathrm{P} 2$ (LHCP3) but not $\mathrm{Chl}_{a / h}-\mathrm{P} 2^{*}$ (LHCP2). MACHOLD et al. showed the results of two experiments, one without $\mathrm{Chl}_{a f h}-\mathrm{P} 2^{*}$ after re-electophoresis of purified $\mathrm{LHCII}$ and one containing a small amount of it (Figure 2, ref.37). With the analytical conditions used here no CPs containing the apoprotein of LHCII (polypeptides F, G, H, Figure 11) have a mobility between those of $\mathrm{Chl}_{a, h}-\mathrm{Pl}$ and $\mathrm{Chl}_{a / h}-\mathrm{P} 2^{* *}$. The results of the present paper are consistent with the results from bean (8) and pea (49) thylakoids where a green band was found in the position of $\mathrm{Chl}_{a / h}-\mathrm{P} 2^{*}$ after re-electrophoresis of $\mathrm{Chl}_{a}-\mathrm{Pl}$.

The spectral characteristics of the $\mathrm{Chl}_{\alpha / h}-\mathrm{P3}$ preparation from bundle sheath thylakoids were similar to previously studied LHCI preparations 
of a comparable polypeptide composition (25, $30,33,49)$. The slightly red shifted absorption at $673 \mathrm{~nm}$ and the $77 \mathrm{~K}$ fluorescence emission at $732 \mathrm{~nm}$ (instead of $730 \mathrm{~nm}$ ) may be due to the simple and rapid method of isolation (about $2 \mathrm{~h}$ long) using the non-ionic detergent octyl $\beta$-D-glucopyranoside in the present study.

Seven polypeptides (Table I) that were present in the $\mathrm{Chl}_{\alpha}-\mathrm{P} 1^{*}$ complex were not found in $\mathrm{Chl}_{\alpha}-\mathrm{P} 1$ nor in $\mathrm{Chl}_{\alpha / b}-\mathrm{P} 2^{*}$. It is concluded that the $\mathrm{Chl}_{a}-\mathrm{P} 1^{*}$ complex is a large aggregate comprising 13 polypeptides. So far a functional role as antenna can be assigned to polypeptides B, $\mathrm{C}, \mathrm{D}$, and as reaction centre of PSI to the 110 $\mathrm{kD} \mathrm{CP}$.

A polypeptide with the same mobility as $\mathrm{E}$ was found after re-electrophoresis of $\mathrm{Chl}_{\alpha / t}-\mathrm{P} 2$, but these might be two polypeptides with different primary structure since in the thylakoid pattern sometimes a doublet can be resolved in this region. Polypeptide $\mathrm{R}$ is present in $\mathrm{Ch}_{a / b}$ $P 2^{* *}$ in both bundle sheath and mesophyll thylakoids but not in the monomeric $\mathrm{Ch}_{a / b}-\mathrm{P} 2$. This polypeptide possibly plays a role in the aggregation of $\mathrm{Chl}_{a / h}-\mathrm{P} 2$ into oligomers.

$\mathrm{Chl}_{a / h}-\mathrm{Pl}$ gives the same polypeptide pattern as $\mathrm{Chl}_{a / b}-\mathrm{P} 2$ after re-electrophoresis. The slight difference in mobility may be due to differing amounts of the bound chl. This is in contrast with that reported from Vicia faba (36) and Chlamydomonas (21) where different apoproteins were found. This may be due to the species specific differences. In barley, for instance, four green bands differing in mobility are found between $\mathrm{Chl}_{a}-\mathrm{P} 2^{*}$ and $\mathrm{Chl}_{a}-\mathrm{P} 2$ (unpublished results).

In granal chloroplasts approximately $60 \%$ of the chlorophyll is associated with LHCII, which is thought to be associated with PSII in the grana stacked membranes (4). The model proposes that little or no LHCII is localized in the stroma membranes where only PSI reaction centres are present. On the other hand a regulatory mechanism for the distribution of the excitation energy between PSI and PSII has been postulated $(20,24,43)$. In response to the redox potential of the plastoquinone pool, the LHCII polypeptides become phosphorylated by a membrane bound kinase. The unbalance of the electrostatic forces caused by this phosphoryla- tion are thought to result in the detachment of the LHCII from PSII $(11,46,54)$ and its migration from grana to stroma lamellae $(7,24$, $31,35)$ where LHCII might serve as an antenna for the PSI (35). LHCII is present in the bundle sheath membranes and the $77 \mathrm{~K}$ fluorescence emission spectra show that it is able to transfer energy efficiently to PSI as well as to fluoresce by itself when it is disconnected from the reaction centre by low amounts of detergents.

The reincorporation of all solubilized CPs into proteoliposomes restores $77 \mathrm{~K}$ fluorescence emission spectrum typical of native thylakoids (44). PSI reaction centres are very effective energy sinks and in nonsolubilized membranes F1 emission is quenched. A similar quenching is illustrated in Chlamydomonas where a mutant lacking the PSI reaction centre emits intense fluorescence at $705 \mathrm{~nm}$ from the antenna designated CPO (56).

MiLLER et al. (39) showed by freeze-fracturing that bundle sheath membranes of maize are virtually identical in structure to the stroma membrane of mesophyll thylakoids. GHIRARDI and MELIS (23) suggested that the functional antenna size of the PSI is the same in mesophyll and bundle sheath chloroplasts. Since a considerable amount of $\mathrm{Chl}_{a / b}-\mathrm{P} 2$ is found in the bundle sheath membranes (Figure 1) the organisation of LHCII and its location in this unstacked membrane becomes an interesting one.

SIMPSON (51) provided evidence that LHCII is localized in the grana PFs particles by showing that in the chl $b$-less barley mutant, these particles are dramatically decreased in number by $80 \%$, whereas at the most a $10 \%$ reduction in the number of PFu particles could be detected in the stroma membranes. A chl $b$-less mutant in maize would be helpful in determining the location of $\mathrm{Chl}_{a / b}-\mathrm{P} 2$ in the bundle sheath thylakoids.

\section{ACKNOWLEDGEMENTS}

I like to thank DITER VON WETTSTEIN for the constant encouragement during the course of this work. DAVID SIMPSON, GAMINI KANNANGara, Ursula Hinz and Gunilla HØYER-HANSEN are thanked for helpful discussions, URSULA HINZ also kindly provided the purified LHCP. ANN-SofI STEINHOLTZ is 
thanked for the colour prints, and NINA RASMUSSEN for drawing the figures. SVEN HARNUNG, H.C. Ørsted Institute is thanked for facilitating the use of the Roussel-Jouen Dichrograph III spectropolarimeter.

The Department of Biology, University of Padua generously provided the financial support for my stay at the Carlsberg Laboratory.

\section{REFERENCES}

1. Allen, J.F., J. Bennett, K.E. Steinback \& C.J. ARNTZEN: Chloroplast protein phosphorylation couples plastoquinone redox state to distribution of excitation energy between photosystems. Nature 291, 25-29 (1981)

2. ANDERSON, J.M., C. WALDRON \& S.W. ThORNE: Chlorophyll-protein complexes of spinach and barley thylakoids. FEBS Lett. 92, 227-233 (1978)

3. ANDERSSON, B., J.M. ANDERSON \& I.J. RYRIE: Transbilayer organization of the chlorophyll-proteins of spinach thylakoids. Eur. J. Biochem. 123, 465-472 (1982)

4. ANDERSON, J.M.: Consequences of spatial separation of photosystem 1 and 2 in the thylakoid membranes of higher plant chloroplasts. FEBS Lett. 124, 1-10 (1981)

5. Anderson, J.M.: P-700 and polypeptide profile of chlorophyll-protein complexes of spinach and barley thylakoids. Biochim. Biophys. Acta 591, 113-126 (1980)

6. Anderson, J.M., J.S. Brown, E. LAM \& R. MALKIN: Chlorophyll b: An integral component of photosystem I of higher plant chloroplasts. Photochem. and Photobiol. 38, 2, 205-210 (1983)

7. Andersson, B., H.E. Akerlund, B. Jergil \& C. LARSSEN: Differential phosphorylation of the light harvesting complex in appressed and non-appressed regions of the thylakoid membrane. FEBS Lett. 149, 181-185 (1982)

8. Argyroudi-Akoyunoglou, J.H. \& G. AkoyuNOGLOU: The chlorophyll-protein complexes of the thylakoid in greening plastids of Phaseolus vulgaris. FEBS Lett. 104, 78-84 (1979)

9. Argyroudi-Akoyunoglou, J.H.: The $77^{\circ} \mathrm{K}$ fluorescence spectrum of the Photosystem I pigment-protein complex CPIa. FEBS Lett. 171, 4753 (1984)

10. ARNON, D.I.: Copper enzymes in isolated chloroplasts. Polyphenoloxidase in beta vulgaris. Plant Physiol. 24, 1-I4 (1949)
11. ARNTZEN, C.J.: Dynamic structural features of chloroplast lamellae. In: Current Topics in Bioenergetics. Eds. D.R. Sanadi \& L.P. Vernon. Academic Press, N.Y. Vol:VIII, $111-160$ (1978)

12. BartzatT, R.A., C.M. YANG \& J.P. MARKWELl.: The interaction of surfactants with the chloroplast thylakoid membrane at sub-solubilizing concentrations. Biochim. Biophys. Acta 725, 341-348 (1983)

13. Bassi, R., A. Dal Belin-Peruffo, R. Barbato \& R. GHISI: Differences in chlorophyll-protein complexes and composition of polypeptides between thylakoids from bundle sheath and mesophyll cells in maize. Eur. J. Biochem. 146, 589-595 (1985)

14. BoArdman, N.K. \& J.M. Anderson: Composition, structure and photochemical activity of developing and mature chloroplasts. In: Chloroplast Development. G. Akoyunoglou et al. Eds. Elsevier pp.1-14 (1978)

15. BRETON, J.: The $695 \mathrm{~nm}$ fluorescence (F 695) of chloroplasts at low temperature is emitted from the primary acceptor of photosystem II. FEBS Lett. $147,16-20(1982)$

16. BRICKER, T.M. \& D.W. NeWMAN: The chlorophyllproteins of soybean (Glycine max L. var. Wayne) cotyledons. Z. Pflanzenphysiol. 104S, 91-96 (1981)

17. BRown, J.S.: Spectroscopy of chlorophyll in photosynthetic membranes. Carnegie Institution Year Book 82, 46-52 (1983)

18. BURKe, J.J., C.L. DitTo \& C.J. ARnTzen: Involvement of the light-harvesting complex in cation regulation of excitation distribution in chloroplasts. Arch. Biochem. Biophys. 187, 252-263 (1978)

19. Butler, W.L.: Energy distribution in the photochemical apparatus of photosynthesis. Ann. Rev. Plant Physiol. 29, 345-378 (1978)

20. Chow, W.S., A. Telfer, D.J. Chapman \& J. BARBER: State 1-state 2 transition in leaves and its association with ATP induced chlorophyll fluorescence quenching. Biochim. Biophys. Acta 638 , 60-68 (1981)

21. Delepelaire, P \& N.H. Chua: Electrophoretic purification of chlorophyll $\mathrm{a} / \mathrm{b}$ protein complexes from Chlamydomonas reinhardii and spinach and analysis of their polypeptide compositions. J. Biol. Chem. 256, 9300-9307 (1981)

22. Gershoni, J.M., S. Sochat, S. Malkin \& I. Ohad: Functional organization of the chlorophyll containing complexes of Chlamydomonas reinhardi. Plant Physiol.70, 637-644 (1982)

23. Ghirardi, M.L. \& A. Melis: Localization of photosynthetic electron transport components in mesophyll and bundle sheath chloroplasts of Zea 
mays. Arch. Biochem. Biophys. 224, 19-28 (1983)

24. Haworth, P., D.J. Kyle, P. Horton, C.J. ARNTZEN: Chloroplast membrane protein phosphorylation. Photochemisty and Photobiology 36, 743748 (1982)

25. Haworth, P., J.L. Watson \& C.J. ARnTZen: The detection, isolation and characterization of a light harvesting complex which is specifically associated with photosystem I. Biochim. Biophys. Acta 724, 151-158 (1983)

26. Henriques, F. \& R.B. Park: Spectral characterization of five chlorophyll proteins. Plant Physiol. 62, 856-860 (1978)

27. Henry, L.E.A. \& B.L. Møller: Polypeptide composition of an oxygen evolving photosystem II vesicle from spinach chloroplasts. Carlsberg Res. Commun. 46, 227-242 (1981)

28. ISH-SHALOM, D. \& I. OHAD: Organization of chlorophyll-protein complexes of Photosystem I in Chlamydomonas reinhardii. Biochim. Biophys Acta 722, 498-507 (1983)

29. Lam, E., W. ORtiz, S. Mayfield \& R. Malkin: Isolation and characterization of a light harvesting chlorophyll protein complex associated with photosystem I. Plant Physiol. 74, 650-655 (1984)

30. LAM, E., W. ORtiz \& R. MALKIN: Chlorophyll a/b proteins of Photosystem I. FEBS Lett. 168, 10-14 (1984)

31. Larsson, U.K., B. Jergil \& B. Andersson: Changes in the lateral distribution of the light harvesting chla/b protein complex induced by its phosphorylation. Eur. J. Biochem. 136, 25-29 (1983)

32. LETO, K.J. \& D. MILES: Characterization of three Photosystem II mutants in Zea mays L. lacking a 32,000 dalton lamellar polypeptide. Plant Physiol. 66, 18-24 (1980)

33. KUANG, T.Y., J.H. ARGYROUDI-AKOYUNOGLOU, H.Y. NAKATANI, J. WATSON \& C.J. ARNTZEN: The origin of the long wavelength fluorescence emission band $(77 \mathrm{~K})$ from photosystem I. Arch. Biochem. Biophys. 235, 618-627 (1984)

34. Kyle, D.J., L.A. Staehelin \& C.J. ARntzen: Lateral mobility of the light harvesting complex in chloroplast membranes controls excitation energy distribution in higher plants. Arch. Biochem. Biophys. 222, 527-541 (1983)

35. Kyle, D.J., T.Y. KuANG, J.L. Watson \& C.J. ARNTZEN: Movement of a sub-population of the light harvesting complex (LHCII) from grana to stroma lamellae as a consequence of its phosphorylation. Biochim. Biophys. Acta 765, 89-96 (1984)

36. Machold, O \& A. Meister: Resolution of the light harvesting chl $a / b$ protein of Vicia faba chloroplast into two different chlorophyll-protein complexes. Biochim. Biophys. Acta 546, 472-480 (1979)

37. MACHOLD,O., D.J.Simpson \& B.L. Møller; Chlorophyll-proteins of thylakoids from wild-type and mutants of barley (Hordeum vulgare L.). Carlsberg Res. Commun. 44, 235-254 (1979)

38. MAROC, J. \& J. GARNIER: Gel electrophoresis of chloroplast membranes of mutants of Chlamidomonas reinhardii which have impaired photosystem II function and lack photosynthetic cytochromes. Biochim. Biophys. Acta 637, 473-480 (1981)

39. Miller, K.R., G.J. Miller \& K.R. MCINTYRE: Organization of photosynthetic membranes in maize mesophyll and bundle sheath chloroplasts. Biochim. Biophys. Acta 459, 145-156 (1977)

40. Mullet, J.E., J.J. Burke\& C.J. ARntZen: Chlorophyll-proteins of photosystem I. Plant Physiol. 65, 814-822 (1980)

41. Mullet, J.E. \& C.J. ARNTZEN: Simulation of grana stacking in a model membrane system. Mediation by a purified light harvesting pigment-protein complex from chloroplasts. Biochim. Biophys. Acta 589, 100-117 (1980)

42. MulLet, J.E., J.J. Burke \& C.J. ARNTZEN: A developmental study of photosystem I peripheral chlorophyll-proteins. Plant Physiol. 65, 823-827 (1980)

43. Murata, N.: Control of excitation transfer in photosynthesis. V. Correlation of membrane structure to regulation of excitation transfer between two pigment systems in isolated spinach chloroplasts. Biochim. Biophys. Acta 245, 365372 (1971)

44. MURPHY, D.J.: The role of acyl-lipids in the reconstitution of photosynthetic membrane functions. In: Structure, Function and Metabolism of Plant Lipids (P.A. Siegenthaler \& W. Eichenberger eds.) Elsevier/North Holland, Amsterdam. pp. 465-489 (1984)

45. MURPHY, D.J. \& I.E. Woodrow: The effects of Triton X-100 and n-octyl- $\beta$-D-glucopyranoside on energy transfer in photosynthetic membranes. Biochem. J. 224, 989-993 (1984)

46. Olive, J., F.A. Wollman, P. Bennoun \& M RECOUVREUR: Ultrastructure of thylakoid membranes in C.reinhardii: evidences of variations in the partition coefficient of the light harvesting complex containing particles upon membrane fracture. Arch. Biochem. Biophys. 208, 456-467 (1981)

47. Ortiz, W., E. Lam, M. Ghirardi \& R. Malkin: Antenna function of a chlorophyll $a / b$ protein complex of photosystem I. Biochim. Biophys. Acta 
766, 505-509 (1984)

48. Remy, R., A. Tremolieres, J.C. Duval, F. AmBart-BretTEVILle \& J.P. DubacQ: Study of the supramolecular organization of the light harvesting chlorophyll-protein (LHCP). FEBS Lett. 137, 271-275 (1982)

49. Remy, R. \& F. Ambart-Bretteville: Evidence for a chlorophyll $\mathrm{a} / \mathrm{b}$ - protein complex associated with photosystem I. FEBS Lett. 170, 174-180 (1984)

50. RiJgersberG, C.P., J. AMESZ, A.P.G.M. THIELEN \& J.A. SWAGER: Fluorescence emission spectra of chloroplast and subchloroplast preparations at low temperature. Biochim. Biophys. Acta 545, 473482 (1979)

51. SimpSON, D.J.: Freeze-fracturing studies on barley plastid membranes. III. Location of the light harvesting chlorophyll-protein. Carlsberg Res. Commun. 44, 305-336 (1979)

52. Simpson, D.J. \& D. von WetTstein: Macro- molecular physiology of plastids XVI. Viridis mutants in barley: Genetic, fluoroscopic and ultrastructural characterization. Carlsberg Res. Commun. 45, 283-314 (1980)

53. ThORnber, P.: Chlorophyll-proteins:Light harvesting and reaction center components of plants. Ann. Rev. Plant Physiol. 26, 127-158 (1975)

54. TorTI, F., P.D. Gerola \& R.C. JenNings: Membrane phosphorylation leads to the partial detachment of the chlorophyll $\mathrm{a} / \mathrm{b}$ protein from photosystem II. Biochim. Biophys. Acta 767, 321-325 (1984)

55. WALDRON, J.C. \& J.M. ANDERSON: Chlorophyllprotein complexes from thylakoids of a mutant barley lacking chlorophyll b. Eur. J. Biochem. 102, 357-362 (1979)

56. Wollman, F.A. \& P. Bennoun: A new chlorophyll-protein complex related to photosystem I in Chlamydomonas reinhardii. Biochim. Biophys. Acta $680,352-360$ (1982)

Accepted by: H. KLENOw, E. LUND and S. O. ANDERSEN 